УДК 338.486.1

Тараненко О.О., к.е.н.

Taranenko A., Candidate of Economic Sciences https://orcid.org/0000-0002-2121-4556

Животенко В.О., к.е.н., доцент

Zhyvotenko V., Candidate of Economic Sciences, Associate Professor https://orcid.org/0000-0003-0511-1802

Шуканов П.В., д.геогр.н., доцент

Shukanov P., Doctor of Geographical Sciences, Associate Professor https://orcid.org/0000-0002-7973-3973

\title{
ТЕОРЕТИЧНІ ОСНОВИ УПРАВЛІННЯ СПОЖИВЧИМИ ПЕРЕВАГАМИ ПІДПРИЕМСТВ ДІЛОВОГО ТУРИЗМУ
}

\section{Вищий навчальний заклад Укоопспілки «Полтавський університет економіки і торгівлі»}

\begin{abstract}
Діловий туризм є важливою складовою світової індустрії туризму. Він грунтується на організації ділових заходів та відряджень співробітників корпоративних клієнтів. Важливість для активізації ділової активності в різних галузях економіки та висока інвестиційна привабливість ринку ділового туризму свідчать про його перспективність та підвищення рівня конкуренції у цій сфері. Обгрунтовано необхідність забезпечення управління споживчими перевагами у сфері ділового туризму комплексно на рівні держави, регіону та туристичного підприємства. На рівні держави мають вирішуватись завдання, пов'язані 3 кадровим забезпеченням, розвитком туристичної інфраструктури, підвищенням технологічного рівня та поліпшення інвестиційного клімату економіки. На рівні регіону необхідно розвивати місцеву туристичну інфраструктуру ділового туризму та популяризувати проведення ділових заходів. На рівні підприємств ділового туризму мають вирішуватися завдання дотримання міжнародних стандартів обслуговування, впровадження інформаційних технологій в надання послуг корпоративним клієнтам. Реалізація цих завдань забезпечить національному ринку ділового туризму конкурентні переваги на міжнародному рівні. Управління споживчими перевагами підприємств ділового туризму повинне грунтуватися як на забезпеченні високої якості та широкого асортименту традиційних послуг для корпоративних клієнтів, так і на активному впровадженні сучасних інформаційних технологій. До них належать програмні продукти, що охоплюють процеси бронювання, управління витратами, звітність і відстеження місця розташування мандрівника; технології проведення повністю або частково віртуальних зустрічей та інших заходів; технології оцифрування платежів і бронювань для забезпечення повністю безготівкових транзакції. Впровадження цих технологій підвищує споживчі переваги підприємств ділового туризму через зростання швидкості операційних процесів та полегшення контролю операційних витрат. Дані інформаційні технології підвищують безпечність надання послуг корпоративним клієнтам, що особливо актуально в умовах непередбачуваного поширення Covid-19.
\end{abstract}

Ключові слова: діловий туризм, інформаційні технологї, конкурентоспроможність, попит, споживчі витрати, управління.

\section{THEORETICAL FUNDAMENTALS OF CONSUMER ADVANTAGE MANAGEMENT OF BUSINESS TOURISM ENTERPRISES}

\section{Higher Educational Establishment of Ukoopspilka «Poltava University of Economics and Trade»}

Business tourism is an important component of the global tourism industry. It is based on the organization of business events and business trips of corporate clients. Business tourism contributes to the intensification of business activity in various sectors of the economy. The business tourism market has a high investment attractiveness and development prospects, which leads to increased competition in this area. The necessity of complex management of consumer preferences in the sphere of business tourism at the level of the state, region and tourist enterprise is substantiated. At the state level, tasks related to staffing, development of tourist infrastructure, raising the technological level and improving the investment climate of the economy should be addressed. At the regional level, it is necessary to develop the local tourist infrastructure of business tourism and promote business events. At the level of business tourism enterprises, the tasks of compliance with international service standards and the introduction of information technology in the provision of services to corporate clients 
should be addressed. The implementation of these tasks will provide the national business tourism market with competitive advantages at the international level. Management of consumer preferences of business tourism enterprises should be based on providing high quality and a wide range of traditional services for corporate clients, as well as on the active introduction of modern information technologies. These include software products that cover the processes of booking, cost management, reporting and tracking the location of the traveler; technologies for holding full or partial virtual meetings and other events; technologies for digitizing payments and bookings to ensure a completely cashless transaction. The introduction of these technologies increases the consumer benefits of business tourism enterprises by increasing the speed of operating processes and facilitating the control of operating costs. These information technologies increase the security of providing services to corporate clients, which is especially actual in the face of the unpredictable spread of Covid-19.

Key words: business tourism, information technologies, competitiveness, demand, consumer expenses, management.

Постановка проблеми у загальному вигляді i ï̈ зв'язок 3 важливими науковими та практичними завданнями. Діловий туризм є самостійним повноцінним видом туризму. Його ключова особливість полягає в обслуговуванні туристичними фірмами не фізичних осіб, а корпоративних клієнтів. Організовуючи корпоративні заходи або обслуговуючи відрядження співробітників, підприємства ділового туризму впливають на економічну активність компаній, галузей та економіки в цілому. Це особливо важливо у нинішній час, коли світова економіка поступово відновлюється від кризових явищ, зумовлених поширенням Covid-19. В таких умовах управління споживчими перевагами підприємств ділового туризму $є$ важливим інструментом відновлення і стабілізації економічних процесів.

Аналіз останніх досліджень, у яких започатковано вирішення проблеми. Дослідженням проблем розвитку ділового туризму займалися I. Андренко, І. Білецька, С. Галасюк, М. Денисенко, Н. Дехтяр, М. Дрогомирецька, П. Конон, Н. Корнілова, Р. Корсак, М. Максимюк, Т. Марусей, С. Музичка, С. Нікітенко, I. Пандяк, I. Прохорчук, I. Ремігайло, О. Шикіна та інші. У своїх працях вони висвітили різноманітні аспекти розвитку ділового туризму в Україні та на міжнародному рівні. Але детальнішого аналізу потребують питання управління споживчими перевагами підприємств ділового туризму.

Цілі статті. Метою роботи $є$ окреслення теоретичних основ управління споживчими перевагами підприємств ділового туризму.

Виклад основного матеріалу дослідження 3 повним обгрунтуванням отриманих наукових результатів. Обсяг світового ринку ділового туризму в 2018 році становив 1,37 млрд дол. і його подальше щорічне зростання очікувалося на рівні 4,9\% до 2,09 млрд дол. у 2027 році [1]. Але на реалізацію прогнозів вплинуло поширення Covid19, що спричинило кризові явища як в міжнародній індустрії туризму загалом, так і в сфері ділового туризму зокрема. У 2020 році порівняно із 2019 роком кількості міжнародних прибуттів зменшилася на $74 \%$ або на 1 млрд туристів, що зумовлено зменшенням попиту на поїздки та введення карантинних обмежень в різних країнах світу [2]. У 2021 році спад на міжнародному туристичному ринку продовжився, про що свідчить зменшення кількості туристів з січня до березня 2021 року на $83 \%$ порівняно 3 аналогічним періодом 2020 року [3]. Незважаючи на кризові явища в туристичній індустрії, діловий туризм відновлюватиметься разом із економічними процесами в різних галузях, оскільки цей вид туризму спеціалізується на організації заходів, що виступають важливими інструментами активізації ділової активності на державному та регіональному рівнях. В узагальненому вигляді ці заходи позначають абревіатурою MICE - від перших літер Meetings (зустрічі, стратегічні, циклічні наради, переговори, презентаціï); Incentives (інсентив, заохочувальні поїздки, мотиваційні програми, стимулювання лояльності партнерів, співробітників, дилерів); Conferences /Conventions (конференції, форуми, конгреси); Exhibitions/Events (виставки, подійний туризм, корпоративні події) [4]. 
Послуги підприємств ділового туризму, що надаються корпоративним клієнтам безпосередньо чи опосередковано пов'язані 3 їхньою діяльністю. Тому до них висуваються підвищені вимоги щодо якості та швидкості надання від чого залежать доходи і прибутки клієнтів.

Забезпечення ефективного управління споживчими перевагами підприємств ділового туризму не $\epsilon$ завданням виключно самих підприємств. До цього процесу мають залучатися низка суб'єктів туристичного ринку відповідно до масштабів прямих i опосередкованих наслідків діяльності підприємств ділового туризму. Тобто, в міру своїх функцій i повноважень органи державної влади на загальнодержавному та регіональному рівні мають сприяти розвитку ділового туризму. Таким чином, управління споживчими перевагами на ринку ділового туризму доцільно розглядати на рівні держави, регіону та туристичного підприємства (таблиця 1).

Таблиця 1

Рівні управління споживчими перевагами на ринку ділового туризму

\begin{tabular}{|c|c|c|}
\hline $\begin{array}{c}\text { Рівень } \\
\text { управління }\end{array}$ & $\begin{array}{c}\text { Напрямки (завдання) управління споживчими } \\
\text { перевагами }\end{array}$ & $\begin{array}{l}\text { Споживчі } \\
\text { переваги }\end{array}$ \\
\hline Державний & $\begin{array}{l}\text { - формування сприятливого інвестиційного клімату в } \\
\text { країні; } \\
\text { - стимулювання розвитку та модернізації туристичної } \\
\text { інфраструктури (фінансові та податкові інструменти); } \\
\text { - ефективне регулювання освітньої діяльності для } \\
\text { підготовки кваліфікованих фахівців у сфері туризму; } \\
\text { - промоція на міжнародному рівні національного ринку } \\
\text { ділового туризму; } \\
\text { - оптимізація туристичних формальностей для іноземних } \\
\text { ділових туристів; } \\
\text { - стимулювання розвитку інформаційних технологій. }\end{array}$ & $\begin{array}{c}\text { Якісна } \\
\text { інфраструктура } \\
\text { Можливості } \\
\text { передових } \\
\text { інформаційних } \\
\text { технологій } \\
\text { Кваліфікований } \\
\text { персонал } \\
\text { Спрощені } \\
\text { туристичні } \\
\text { формальності } \\
\end{array}$ \\
\hline $\begin{array}{l}\text { Регіональний } \\
\text { (місцевий) }\end{array}$ & $\begin{array}{l}\text { - стимулювання розвитку та модернізації місцевої } \\
\text { туристичної інфраструктури, в тому числі для ділового } \\
\text { туризму (бізнес-центри, виставкові зали, конгрес-центри); } \\
\text { - сприяння організації та проведенню масштабних ділових } \\
\text { заходів (виставок, конгресів, конференцій ) }\end{array}$ & $\begin{array}{c}\text { Якісна } \\
\text { інфраструктура } \\
\text { Спрощені } \\
\text { бюрократичні } \\
\text { процедури } \\
\text { організації } \\
\text { ділових заходів } \\
\end{array}$ \\
\hline $\begin{array}{l}\text { Підприємства } \\
\text { ділового } \\
\text { туризму та їх } \\
\text { об'єднання }\end{array}$ & $\begin{array}{l}\text { - впровадження міжнародних стандартів в обслуговуванні } \\
\text { корпоративних клієнтів; } \\
\text { - забезпечення широкого асортименту традиційних та } \\
\text { інноваційних послуг; } \\
\text { - впровадження інформаційних технологій в процес } \\
\text { обслуговування корпоративних клієнтів (технології } \\
\text { віртуалізації зустрічей та інших заходів, автоматизації } \\
\text { надання послуг, оцифрування платежів і бронювань); } \\
\text { - використання традиційних (участь у виставкових } \\
\text { заходах, реклама в ЗМІ) та новітніх (соціальні мережі, } \\
\text { таргетинг) засобів просування власних послуг. }\end{array}$ & $\begin{array}{c}\text { Широкий } \\
\text { асортимент } \\
\text { послуг } \\
\text { Висока якість } \\
\text { послуг } \\
\text { Оперативність } \\
\text { надання послуг } \\
\text { Безпечність } \\
\text { послуг в } \\
\text { умовах } \\
\text { поширення } \\
\text { Соvid-19 } \\
\end{array}$ \\
\hline
\end{tabular}

Лише комплексна взаємодія органів державної влади на різних рівнях та підприємств ділового туризму забезпечить національному ринку ділового туризму конкурентні переваги, що дозволять зайняти вагоме місце на міжнародному ринку ділового туризму.

Управління споживчими перевагами на рівні підприємства ділового туризму повинне грунтуватися на забезпеченні незмінної високої якості туристичного продукту 
та впровадження передових інформаційних технологій в обслуговування клієнтів.

Туристичний продукт для клієнтів підприємств ділового туризму є комплексом туристичних послуг для реалізації мети ділового заходу, який формується клієнтом із запропонованого підприємством переліку. Цей перелік може включати традиційні та інноваційні послуги, залежно від можливостей туристичного підприємства. До традиційних послуг належать: візова підтримка; трансфер та проживання учасників; організація прискореної процедури розміщення в готелі, персонального Help Desk в місці проведення заходу та у місці проживання учасників, vip-зустрічі; вибір місця проведення заходу; транспортне обслуговування різними видами транспорту; допомога в організації конференції, в тому числі оренда конференц-залів і надання технічної підтримки протягом всього заходу; забезпечення друкованою та рекламною продукцією; розробка i проведення team-building-заходів, конкурсів, спортивних змагань та виступів; підготовка допоміжної документації; організація екскурсійно-розважальної програми; надання координатора, який буде супроводжувати групу протягом всієї поїздки та допоможе у вирішенні будь-яких питань та інше.

Якісне надання традиційних послуг підприємствами ділового туризму $\epsilon$ правилом, тому для успішної конкурентної боротьби вони мають активно впроваджувати інноваційні рішення у сам процес обслуговування клієнтів або пропонуючи нові інноваційні продукти. В умовах пандемії Covid-19 та непередбачуваності її подальшого поширення особливої актуальності набуває практика впровадження інформаційних технологій в обслуговування корпоративних клієнтів. Вони забезпечують дотримання санітарно-епідеміологічних норм, що запроваджені в більшості країн світу.

Одними 3 важливих напрямків обслуговування корпоративних клієнтів $є$ оцифрування платежів і бронювань. Це забезпечується низкою сервісів онлайн i безготівкової оплати туристичних послуг без використання кредитних/дебетових карт або мережевих банківських операцій. Такі транзакції безпечні і легко відслідковуються з метою контролю витрат та їх оптимізації. Також активно розвиваються сервіси Apple Pay, Samsung Pay, Paytm, Venmo і інші цифрові способи оплати, що грунтуються на використанні віртуальних номерів рахунків (VAN) і забезпечують повністю безготівкові транзакції [5]. Впровадження даних технологій спрощує здійснення розрахунків, підвищує швидкість операційних процесів та полегшує контроль операційних витрат корпоративними клієнтами.

До актуальних інформаційних технологій в умовах карантинних обмежень належать технології проведення повністю або частково віртуальних зустрічей та інших заходів. Для цього використовуються рішення для прямої трансляції, платформи вебмовлення, мобільні додатки для заходів, інтеграція управління відвідувачами 3 програмним забезпеченням для веб-конференцій, платформи для віртуальних заходів і виставок.

Також підвищує рівень споживчих переваг підприємства ділового туризму впровадження програмних продуктів, що охоплюють такі найважливіші процеси, як бронювання, управління витратами, звітність і відстеження місця розташування мандрівника тощо. Окремо слід виділити додатки та програми, що використовуються для планування, організації та супроводу ділових заходів (Shoflo, EventGeek, Fly Another Day, GruupMeet та інші). Вони дозволяють: створювати виробничі листи, графіки продуктів, списки і документи в режимі реального часу; співпрацювати і керувати логістикою подій, в тому числі місцями, постачальниками, печаткою, доставкою, подорожами і бюджетами; управляти місцем проведення заходу, груповою реєстрацією і системою обміну подіями та інше [6]. Такі продукти стали традиційними для найпотужніших гравців ринку ділового туризму на міжнародному рівні, зокрема 
American Express Global Business Travel, BCD Group, Booking Holdings Inc., Carlson Wagonlit Travel, Direct Travel Inc. та деяких інших.

Забезпечення високої якості традиційних послуг із впровадженням сучасних інформаційних технологій забезпечить підприємствам ділового туризму досягнення оптимального рівня споживчих переваг для функціонування та конкуренції в сучасних складних кризових умовах.

У забезпеченні споживчих переваг підприємствами ділового туризму окремо слід виділити їх об'єднання. Традиційно їх завданнями є: вплив на правове регулювання галузі; участь у підготовці висококваліфікованого кадрового потенціалу галузі; консалтингова допомога учасникам; упорядкування конкурентного середовища у галузі; представництво учасників на міжнародному рівні та інші. Такі об'єднання створюються як на загальнодержавному (наприклад, Асоціація ділового туризму України (Business Travel Association of Ukraine)), так і на міжнародному (наприклад, Світова асоціація ділового туризму (Global Business Travel Association)) рівнях.

Висновки. В нинішній час зростає інвестиційна привабливість ринку ділового туризму, що зумовлює його розвиток та посилює рівень конкуренції у цій сфері. В таких умовах зростає актуальність завдання забезпечення ефективності управління споживчими перевагами підприємств ділового туризму. Цей процес $є$ складним i потребує державної підтримки на національному та регіональному рівнях. Управління споживчими перевагами підприємства ділового туризму повинне грунтуватися на забезпеченні незмінної високої якості традиційних туристичних послуг та впровадження передових інформаційних технологій в обслуговування клієнтів.

\section{Список бібліографічного опису:}

1. Global \$2.09 Bn Business Travel Market Analysis and Forecasts to 2027. URL : https://www.prnewswire.com/newsreleases/global-2-09-bn-business-travel-market-analysis-and-forecasts-to-2027--300924093.html (дата звернення: 15.07.2021).

2. 2020: worst year in tourism history with 1 billion fewer international arrivals. URL: https://www.unwto.org/news/2020worst-year-in-tourism-history-with-1-billion-fewer-international-arrivals (дата звернення: 15.07.2021).

3. UNWTO WORLD TOURISM BAROMETER. URL: https://www.unwto.org/unwto-world-tourism-barometer-data (дата звернення: 16.07.2021).

4. Асоціація ділового туризму України. URL : http://btaukraine.com/wp-content/uploads/2015/09/STATUT-BTA-Ukraine2015.pdf (дата звернення: 16.07.2021).

5. Business Travel Market to 2027. URL : https://www.researchandmarkets.com/reports/ 4825292/business-travel-market-to2027-global-analysis (дата звернення: 17.07.2021).

6. Музичка Є. О. Тенденції розвитку світового ринку МICЕ-туризму. Ефективна економіка. 2019. № 2. URL: http://www.economy.nayka.com.ua/?op=1\&z=6910 (дата звернення: 17.07.2021).

\section{References:}

1. Global \$2.09 Bn Business Travel Market Analysis and Forecasts to 2027. URL : https://www.prnewswire.com/newsreleases/global-2-09-bn-business-travel-market-analysis-and-forecasts-to-2027--300924093.html [in English].

2. 2020: worst year in tourism history with 1 billion fewer international arrivals. URL: https://www.unwto.org/news/2020worst-year-in-tourism-history-with-1-billion-fewer-international-arrivals [in English].

3. UNWTO WORLD TOURISM BAROMETER. URL: https://www.unwto.org/unwto-world-tourism-barometer-data [in English].

4. Asotsiatsiia dilovoho turyzmu Ukrainy. URL : http://btaukraine.com/wp-content/uploads/2015/09/STATUT-BTA-Ukraine2015.pdf [in Ukrainian].

5. Business Travel Market to 2027. URL : https://www.researchandmarkets.com/reports/ 4825292/business-travel-market-to2027-global-analysis [in English].

6. Muzychka Ye. O. Tendentsii rozvytku svitovoho rynku MICE-turyzmu. Efektyvna ekonomika. 2019. № 2. URL: http://www.economy.nayka.com.ua/?op=1\&z=6910 [in Ukrainian].

Дата подання публікації 30.07.2021p. 